\title{
Towns, Plots, Crafts and Fertility Traces of a Power Ideology
}

\author{
Anna Hed Jakobsson
}

Change is always related to past experience. In this article it is argued that the spatial organization of the earliest towns in Scandinavia, in spite of their novelty, reflected old concepts and beliefs. The hypothesis is that the placing of buildings, the parcelling out of plots etc. in a Viking Age town such as Birka, referred to still vital concepts of fertility, creativity and wealth - and the power over these things. One aspect of the argument is that there existed a metaphorical relationship between the fertile field in the countryside and the productive town plot, where skilful smiths created valuable things.

Anna Hed Jakobsson, Department of Archaeology, Stockholm University, SE-106 91 Stockholm, Sweden.

\section{INTRODUCTION}

The urbanization of the Nordic countries has been considerably discussed, and the concept of "town" defined in a number of ways. In most studies this has been done retrospectively, that is, the emergent new structures have been interpreted in the light of subsequent developments. But how are we to understand what these places represented in their own time? As has been pointed out (Andrén 1994; Christophersen 1997) urban archaeology has for a long time followed in the wake of the historians. This has brought forth a research directed towards economic and juridical matters. These aspects of the early towns are of course important, but we cannot presuppose that they were as crucial in the past as we find them today. There is a risk, I believe, that if the cultural features of the earliest towns do not generate more interest than has been the case previously, the real importance of them may elude us (cf. Harrisson 1997).

The point of departure for the following discussion is that spatial relations and the layout of architectural forms can be treated as parts of a conceptual structure. Therefore, by studying spatial relationships in the early towns we may come closer to an understanding of what these places may have represented in past people's minds. In this text I will present the hypothesis that the spatial organization of the earliest towns, in spite of their novelty, might have reflected old concepts and beliefs. The placing of buildings, the parcelling out of plots, etc. referred to notions of fertility, creativity and wealth, and the power over these things. One important aspect of the argument is that there existed a metaphorical relationship between, on the one hand, the fertile field in the countryside and, on the other hand, the productive town plot, where smiths created valuable things.

\section{THE NOVELTY OF CENTRAL PLACES AND TOWNS}

Usually the Merovingian and Viking towns, for example Ribe or Hedeby in present-day 
Denmark and Germany or Birka in Sweden, are seen as structures completely new and previously unknown in the Nordic areas. This might, however, not be the case. During the last fifteen years or so a number of central places have been found that belong to an earlier period. One example is GudmeLundeborg on Fyn in Denmark (Blæsild et al. 1993), while another is Uppåkra in Scania, in present-day Sweden (Hårdh \& Larsson 1998). Both these places, together with several like them, have probably been important centres from the third to the sixth century (although the finds from Uppåkra mainly belong to the seventh to tenth centuries). According to Anders Andrén (1998:148), although their physical appearance is very little known, each of these older places must be considered as a kind of "prehistoric city". Notwithstanding this, something new is obviously being created during the eighth century, when places like Ribe, Hedeby and Birka emerge.

Previous research has stressed the fact that these early towns had new and special functions. Prevailing ideas concern the towns as a mean of controlling vital resources like the trade and exchange of commodities, being, as they were, "ports-of-trade" or "emporia" in evolving kingdoms or early states. They are supposed to embody new ideas, and consequently they are seen as something rather alien to their local environment. Their localization to coasts or islands, and their spatial organization with built-up areas demarcated by walls and extensive piling outside the harbours, seem to support this notion (cf. Andrén 1998:151). The foreign connection is also underlined by the fact that it was to these places foreign merchants, emissaries and missionaries seemingly chose to locate their activities (cf. Vita Anskarii).

When stressing this novelty and estrangement, however, it becomes difficult to understand how the earliest towns interplayed with their surroundings. Why were they accepted? Through recent research it has become clear that e.g. the island of Björkö, where the
Viking town of Birka was situated, could not have supported its presumed population (of between 500 and 1000 persons; Ambrosiani 1985:107). The town needed supplies of food, fuel, timber, raw materials etc., and the importance of having good relations with the surrounding countryside can hardly be overestimated (Bäck 1997). Excavations in Birka's hinterland do point to close contacts between the town and its neighbouring areas (ibid). What, then, made the town legitimate? Was it the military force (the threat of violence) of its powerful initiators, probably a royal family? Or was it the prospect of making big profits by associating oneself with the town dwellers and/or the market there?

As will be obvious, I think neither of these propositions (somewhat bluntly expressed) covers the situation, although they cannot be ruled out completely. Reasons and motives behind the emergent urban structures, as well as the consequences resulting from their presence, were of course very complex. In this text, however, I choose to suggest one possible meaning that the new towns may have had, a meaning that made them acceptable and/or understandable to people affected by them. Keywords are, as stated above, spatial organization, power, legitimacy, as well as ancient ideological concepts such as fertility and creativity. I shall approach these concepts by bringing together a number of source materials, using both archaeological and written evidence as well as art.

\section{CREATIVITY AND POWER}

The society during this period (the Late Iron Age) seems to have been rather mobile. Hierarchies were not fixed, and institutions and bureaucracies were absent. This created a need for constant legitimation of the social hierarchy and prevailing power relations. I think it is against this background that we should evaluate the vague evidence we have of what has been referred to as a "sacred kingship" in Scandinavia during this period. The concept has been severely criticized and 


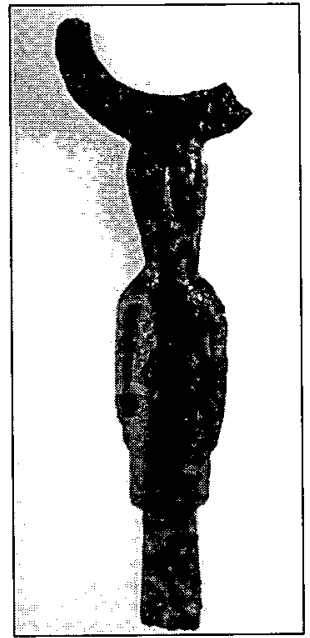

Fig. 1. A bronze figurine of the pagan god Odin. Found in Uppakra, Scania. (After Hårdh \& Larsson 1998:147, fig. 13).

considered obsolete, but it seems as if it is getting renewed and more positive attention. This re-evaluation owes much to the fact that archaeological excavations in recent years have confirmed that the exercise of power was linked to religious beliefs and practices. Notable examples are, for example, places like Slöinge in Halland (Lundqvist 1996, 1997a, b), Borg in Östergötland (Lundqvist et al. 1996; Nielsen 1997) and Sanda in Uppland (Áqvist 1992, 1998), all in present-day Sweden. Not to mention giants like the famous Uppsala in Uppland, or Uppåkra in Scania (Hårdh \& Larsson 1998). The elements in these places that have been identified as traces of religious activities include sacrificed and/or ritually deposited objects, sacrificed animals, amulet rings or figurines depicting pagan gods (fig. 1), and the presence of cult buildings. All of these places also show features usually associated with power, such as access to fertile soils or other natural resources, a settlement location that sets them apart from other farms, certain place-names, graves or cemeteries that distinguish themselves by their design, a known later history as royal manors or estates, etc.

Of course, to separate the sacred (e.g. use of amulet rings) and the profane (e.g. access to natural resources) in this way is a result of our modern way of thinking. Past reality was hardly that divided, and the idea that religious beliefs and practices only served to legitimate a concentration of power that in fact resulted from economic dominance cannot be upheld (cf. Godelier 1982). An illustration of the problem can be given by using material from the excavated Late Iron Age farm of Borg in Östergötland, as it has been described by the excavators (Lindeblad 1996; Nielsen 1997).

The excavation of the farm revealed buildings that were interpreted as associated with cult activities. These houses all differed in design from the dwelling-houses on the site, and they seem to have been placed in an area separated from the dwelling-site by trenches filled with stones and waste from the slaughtering of animals.

Outside one of the buildings (house 5; Nielsen 1997:278ff) was found a hoard of nearly a hundred amulet rings, and a lot of bones from sacrificed animals. Next to the amulet rings there was also quite a lot of iron slag, fragments of blast nozzles, and a couple of furnaces which can be associated with iron production. As stated by the excavators, the artefacts and structures found at house 5 in Borg represent a complete process, from iron production to forging and the deposition of amulets (Nielsen 1997:384). Together with the sacrifices of animals and the cult building it seems obvious that these remnants must be interpreted as traces of cult activities. Much speaks in favour also of the interpretation that there was a powerful family living at Borg. But what gave them their position? According to one hypothesis (Lindeblad 1996:63ff), among other things they controlled the market-and/or production-site which was found close to the farm at Herrebro, and which functioned in the same period as the "cultic events" in Borg (ca. A.D. 700-1000). But how were the "cultic" iron production and forging at the farm related to the crafts practiced at Herrebro? Were they related? Might there be a connection? Is it obvious that Herrebro shall be viewed as a wholly "profane" place? The questions are, of course, rhetorical. 
TOWNS, CRAFTS AND POWER

The concept of town is intimately linked to the concepts of crafts and trade. In fact, most suggestions on how to define a town contain references to these concepts. To pass as a town, a place must show some kind of economic specialization, preferably crafts and trade. And in most centres of the Late Iron Age we find evidence of sometimes extensive, and often exclusive, craft production. (Of course we should be aware of a possible vicious circle here: the presence of crafts indicating that we are dealing with a centre...)

Much speaks in favour of the opinion that places with specialized crafts and a surplus production of valuable things were in the hands of big farms and powerful families. This is a structure that was probably established during the Migration period, and maybe even earlier, in the Late Roman Iron Age (Blæsild et al. 1993; Andersson 1995:117), and it lives on well into the Viking Age. A few places can be mentioned briefly: GudmeLundeborg, Dankirke, Stentinget, Bejsebakken, Neble and Boeslund in Denmark; the Black Earth (Sorte Muld) on Bornholm; Helgö in Lake Mälaren, Sweden, or Högom in the province of Medelpad, also in Sweden. During the Merovingian and Viking periods this pattern, as I see it, continues when places like Ribe, Hedeby, Åhus, Kaupang, Birka, and others are established. Each of these places has its own character, which is not surprising since they belong to different regions and have functioned in different contexts. All the same, and rightfully I think, they are usually interpreted in much the same way, as structures controlled by kings and powerful families.

The presence of an extensive production of different commodities is often explained by references to the theory of gift exchange, as it has been developed by Mauss (1925, and elaborated on later by e.g. Polanyi 1959; Bourdieu 1977, 1990). Most scholars agree that the Late Iron Age society should be characterized as a "gift-society" (cf. Duby
1981; Lindkvist 1988). That is, it was a society where the exchange of things in the form of gifts - the gift being permeated with the power of the giver and his charisma created different "social contracts", since the receiver was bound by the gift and had to repay it either with a gift or with loyal services. Needless to say this made it necessary to be able to control the manufacture, or influx into a territory or domain, of valuable "gifts-tobe". Towns, market-places, production-sites etc. were therefore created and/or controlled by different magnates. These magnates were, however, not only violent entrepreneurs. They were also believed to be "descendants of the gods" (Skre 1998:291).

As stated above, the concept of sacred kingship is undergoing a re-evaluation. To judge from the written and archaeological sources, it seems as if kings (and other magnates) at least in some respects were thought of as "descendants of the gods" and were also believed to have the power to bring their people fecundity and peace-ár ok fridr. This ideology was probably manifested in different rituals, for instance in sacrificial feasts. The cult(s) was of course carried out on different levels of society. Not only big public gatherings that drew whole districts or realms are mentioned in the sources, but also ceremonies conducted at single farms. That kings participated in some events does not imply that they were the only possible or necessary cult leaders or participants. Instead the kings in this respect as well as in many others should probably be looked upon as primus inter pares (Baetke 1973:186; Meulengracht Sørensen 1991:242). The large sacrificial feasts or gatherings were, however, most likely connected with the highest strata in society. It was here that the leaders; the chief, godi, jarl or king could play the main character in staged encounters with the gods. The purpose was to further the prosperity of their people. (We can of course suspect that the institution had other functions as well, for instance to define the own group and 
create a sense of community within this group, with other groups and with the gods.) (Baetke 1964:51-68; Ström 1985:81; Drobin 1991:97; Hultgård 1993:248).

Research has long recognized that the big cult events and feasts were accompanied by markets. That this was the case is usually seen as simply a way to "exploit the moment" and engage in trade when a lot of people were already gathered. But the trade and exchange can just as well be seen as a vital part of the "cultic" event as a whole. It is, I think, reasonable to view the markets and gift exchanges, as well as the production of the items transferred, as part of the belief that a king, powerful person or family could and should create wealth. The person that could create wealth proved him- or herself worthy of the powerful position: the man that could create wealth was king. The enormous production of things known from places like Ribe or Birka may have been a way to demonstrate a mighty ability to create wealth, ár ok fridr. On a smaller scale we encounter this phenomenon also in places such as the abovementioned Herrebro (Lindeblad \& Nielsen 1997:113; cf. Andersson 1995:117 with refs., Callmer 1995). Thus, production was an objectification of powerful people's ability and knowledge of how to bring forth wealth.

Knowledge is a keyword. The creation of wealth demanded certain knowledge knowledge of how to let loose, in a controlled way, those forces that made the creation of wealth possible (cf. below). The origin of this conceptual structure can perhaps be found already in the late Roman Iron Age, and it lives on at least until the end of the tenth century, perhaps even longer. I consider it an interesting coincidence, but probably not mere chance, that the so-called animal art was created during the same period.

\section{CREATIVITY AND ART}

I would like to suggest that animal art in all its variety on a general level can be seen as a sign, denoting transformation. What the images of the animal art show is a conversion or transformation as it actually happens. The art expresses a state in between, between nature and culture or between the potential and the finished. That is why the art seems to have been used in contexts of uncertain conditions, of boundaries and liminal states.

From the Migration period and well into the early Middle Ages the Germanic and above all Nordic art were dominated by the so-called animal art. The characteristics of this art are the tearing apart and the intertwining. The images are made up of strange animals who are torn to pieces, their heads, thighs and feet turning and dancing around in a sometimes wild and sometimes highly stylized manner. The art lack any claims of being realistic representations, which makes it difficult to find the images meaningful. Thus, they are usually, as the name ( $\mathrm{Sw}$. djurornamentik) implies, considered as mere ornaments without any specific meaning other than e.g. as valuable items in a general context of social strategies. The constant reproduction of these forms during such a long time, however, shows that they were indeed full of meaning. I also think that the lack of resemblance to given things is the actual key to understanding the art.

My thought is that the animal art symbolizes something that does not yet exist, something that has been and shall become. If we are to look for a "natural" reference to this way of representing change and transformation, the item of jewellery that is torn apart and melted down and then reshaped into something new might be a parallel. It is therefore interesting that the animal art was originally a metal art. This fact has also been put forward by Siv Kristoffersen (1995, 1997). Using Claude Lévi-Strauss' ideas on Asian and American primitive art (1963), Kristoffersen (who deals primarily with the early animal art of Style I) maintained that the pictures have a deeper purpose than mere decoration. According to Kristoffersen, the animal art was intended to transform the 
decorated things into forceful and ritual objects.

The choice of animals is logical. Animals are both like and unlike humans, which makes them suitable to use in ritual contexts (Kristoffersen 1995; cf. Bloch 1992). And it is a characteristic feature of some of the animal art motifs that animals and humans are intertwined (Vierck 1967; Haseloff 1981; Hauck 1985; Roth 1986) (fig. 2). The metamorphosis of human-animal shown in the art is also a characteristic feature of preserved myths. In the myths and sagas there is no fixed border between man and animal. Especially in connection with different transgressions and processes of creation the people of the myths - heroes and gods or their souls - are often transformed into the shape of an animal (so-called hamnskipti), take on traits of animals or animal-like creatures (cf. the berserks), or are followed by the animalshaped alter ego, the fylgja (Ström 1985:206).

A third reason is that animal art is dominated by snakes and dragons, animals that are perfectly suited to express liminality or

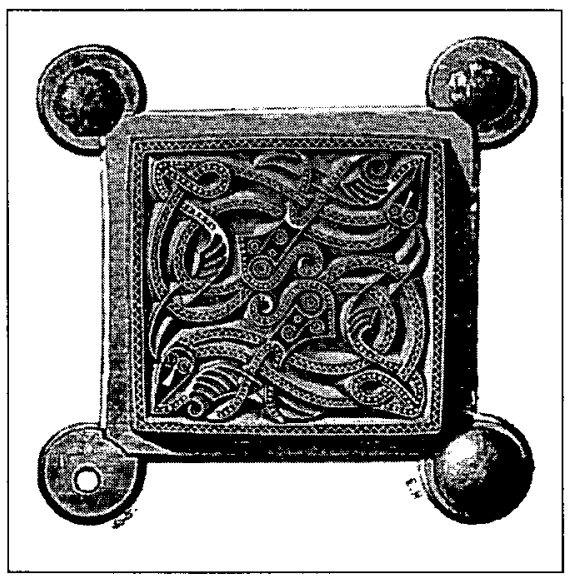

Fig. 2. A mount from Vendel grave XII (after Aberg 1925:99, fig. 181). The image shows the confusing intermingling of man and animal. There are more pictures like this found in the Vendel boatcemetery, some of which show women intermingling with, or transforming into, animals (cf. Stolpe \& Arne 1912).

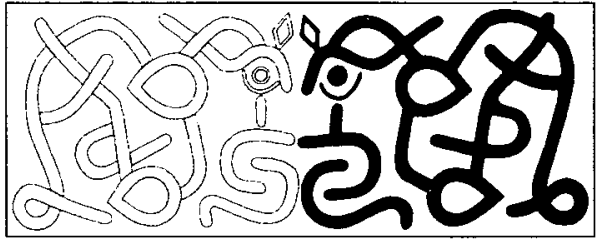

Fig. 3. A kenning of Old Norse poetry is always constituted of at least two words or concepts. It is the relationship between these concepts that is signifying. The same technique has been used in the animal art. Two horse's heads seen in profile may form e.g. a man's face or a mask seen en face. This picture-kenning probably signified a third thing, e.g. strength or loyalty. (From Haseloff 1981:252, fig. 165b.)

"conditions of in-between" (Johansen 1997:153).

In the kenning of the Nordic poetry we find many similarities to the picture-language, that is, the animal art. The similarities have been observed by many scholars, among others Hallvard Lie in his important work Skaldestilstudier (1952). According to Lie, the poetry was a verbal equivalent to the visual art. Both art-forms were dependant on a specific cultural environment, where "basically an unorganic, unnaturalistic sense of design was totally dominating, where 'art' first and foremost strove to hold nature at a distance and create the magical line-pattern that bound and controlled the 'powers'..." (Lie 1952:3, my transl.).

A kenning, unlike other poetic metaphors, is always composed of two separate words or concepts which individually do not capture what is being described, but which in combination are signifying. One example might be "the horse of the sea", which is a kenning designating "ship". In animal art the same technique is used. Two horse's heads seen in profile may form, for example, a man's face or a mask seen en face (fig. 3).

Like Lie, Ladislaus Mittner meant that the kennings expressed something essential about the heathen conception of the world. They were not only literary extravaganza, but 
constituted the very meaning of the poetry (Mittner 1955:13). Mittner thought of the kennings almost as sympathetic-magic, that is, they were regarded as having real effects upon the world, and they mirrored a worldview where all things could be transformed and qualities could be transferred between them (Mittner 1955:9f, cf. Eliade 1978:143f). The ship that was compared to a horse, for example, actually had the traits of the horse, such as moving fast or obeying its rider. In the animal art we see how the horse and the man are transformed into each other and thereby acquire each other's qualities. Also, the man and the horse together probably formed a pictorial kenning of, for example, strength or loyalty.

Objects that were decorated with animal art were probably used to indicate different cultural transformations. The change from a biological individual to a social person may have been one such transformation, the context of funeral another (Kristoffersen 1997:247). An interesting example of the first situation is found in the Völsungasaga, in which the hero Sigurd kills the dragon Fafnir (fig. 4). When Sigurd has killed the dragon and become a mature man with (nota bene) the rank of king, he "wears emblems with dragons all over his attire" (Schjødt 1994:1 18, my transl.). A similar example is found in
Beowulf, in which the hero after his victory over the monsters in their cave beyond the world can hand the sign of victory over to King Hrothgar, the sign being a golden sword-hilt adorned with runes and snakes (Beowulf, v. 1687-98; cf. Bauschatz 1982:100f).

In the myths important actions and events are often followed by the presence of a dragon or snake. This is especially obvious when the story is about males becoming adults, nature being tamed, or land conquered (LeGoff 1980:180ff; Bauschatz 1982:130; Johansen 1997:148ff). These are all events that can be connected with the concepts of nature and culture, and with change, the process of becoming, and creation.

\section{TO CHANGE NATURE INTO CULTURE}

The dichotomy of nature-culture is not unproblematic when dealing with prehistoric periods. Today we consider nature to be a resource for us to exploit, but at the same time nature is seen as an entity with a specific value, being pure, simple and good. The preChristian world-view does not seem to have regarded nature and culture in terms of good or bad, high or low; rather, perhaps, as unfinished and finished. One illustration of this is that nature in mythology is represented by giants who, paradoxically enough, are

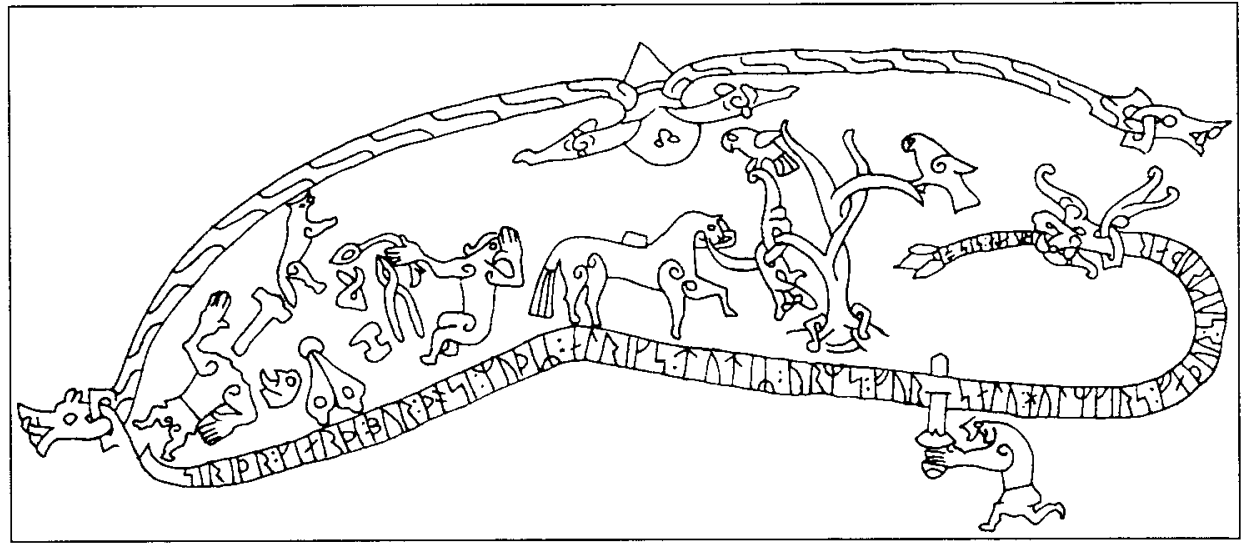

Fig. 4. This image of the struggling and victorious Sigurd is carved into a rock in the parish of Jäder, Södermanland. It can be dated to the early IIth century. (From Johansen 1997:82) 
described as deformed and unnatural. In the stories of the god Thor fighting against giants and giantesses there is a recurrent theme of him making them more natural by, for example, chopping off their extra arms or heads (Clunies Ross 1994:68f and refs.). Thus, it seems as if the mythology actually holds the opposition nature-culture (as well as the oppositions male-female and orderdisorder (Schjødt 1991; Clunies Ross 1994)). If Sigurd is to become a man he has to transgress a boundary and encounter the "other world" by killing the dragon and meeting the valkyrie Sigrdrifa. The myth is a variation on the theme that growth, creation and fullfilment demands the crossing of borders. Another variation on this theme is the gods' desire to capture different objects in the land of the giants, a place which, with modern language, could be understood as nature. The things that the gods long for are always unfinished; they are only potential valuables until the gods, regin (the "ordering powers", Mundal 1990:7), lay their hands on them (Clunies Ross 1994: 83, 105f, 187ff). From the perspective of power ideology it is interesting that the genealogies of the Late Iron Age ruling families usually begin with a marriage between gods, regin, and giantesses (Mundal 1990; Steinsland 1991). In that way the rulers held among them both order and disorder, culture and nature.

\section{SMITHS OF METAL, SMITHS OF RHYME}

In the Eddaic poem Völuspá there is an account of how the creation of the world was completed: "The Æsir met at Idavelli; they built altars, high timbered halls, fashioned hearths to forge gold treasure, strong tools and heavy tongs" (transl. Terry 1969, after Nielsen 1997:384). Smithery is linked to the creation of the world. The Esir are skilled smiths, and the most outstanding creator is Odin. Can the reverse also be true, that the smith possessed god-like qualities?

There are many similarities between Odin

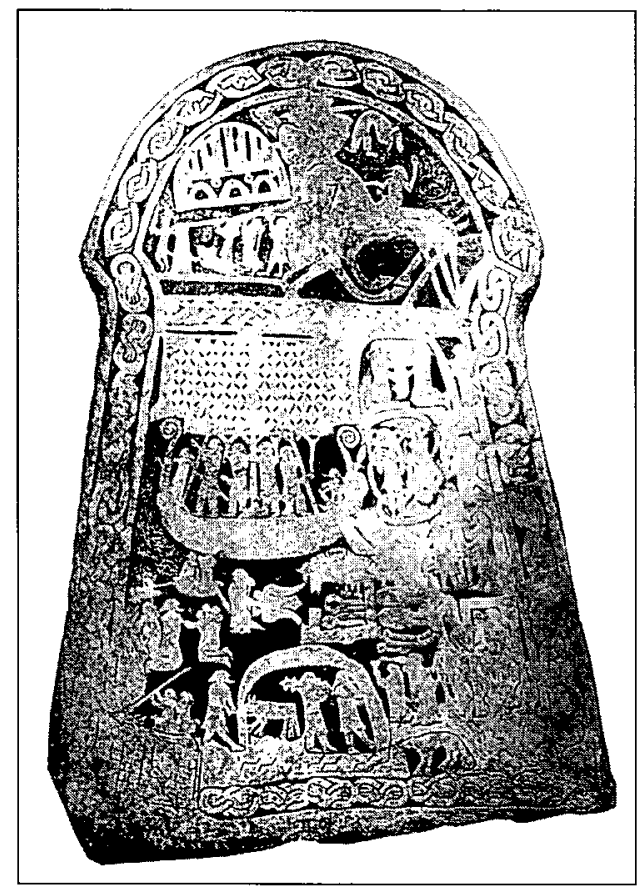

Fig. 5. The Gotlandic picture-stone Ardre VIII shows motifs from the myth of Volund (Weyland) the Smith, and his captivity by King Nidud. To the left of the smithy we see Volund escaping by turning himself into a bird.

and the master-smith Völund (fig. 5). Just like Odin, Völund is able to transform himself into different animals (hamnskipti), and like Odin he has been taught his skills by Mimir, a personification of the highest wisdom (Buchholz 1971:19; Drobin 1991). Odin has been seen in the guise of a smith. Odin is associated with shamanism (Hedeager 1997), and often the shamans were skalds and smiths (Buchholz 1971:18; Roth 1986:145, cf. Eliade 1978:106). Odin is a master of runes and of secret knowledge. It is therefore logical that the oldest runic inscriptions speak of who made the particular object.

Another indication of the position the smiths may have held is that they were long believed to be in contact with divine powers. Their knowledge of how to transform bogore into ploughshare-blades or sword-blades, 
or how to pour liquid bronze into clayforms and conjure forth shining buckles, has been associated with supernatural powers (Christiansen 1982).

A distinctive feature of the smith's work is that he creates by transforming one thing into another. His work resembles a ritual, since the manufacture of objects out of ore (or other materials) demands that the work be executed in a certain order which can not be reversed without disastrous results. Several archaeological and ethno-historical studies have demonstrated that metal-production and smithery have often been surrounded by certain conceptions, often linked to notions of fertility, growth and change (Collett 1993; Rowlands \& Warnier 1993, cf. Hodder 1998:5ff; Eliade 1978), and this indeed seems to have been the case also in the Nordic Late Iron Age (Burström 1990; Ersgård 1997; Isendahl 1997).

Thus, the smith was an expert at specific rituals that aimed at changing ore into objects, or in other words transforming nature into culture. The specific knowledge required to do this is certainly what lies behind the mythical character Regin, the smith that has such an important role in the Völsungasaga. Sigurd is fostered by Regin, and Regin is his initiator, encouraging Sigurd to kill the dragon with the powerful sword he has forged.

There has been a lively discussion on what position the smiths held in Late Iron Age society (Andersson 1995:115ff summarizes this debate). There is not enough space here to dwell on it, so suffice it to say that I think it is a mistake to regard the "economic" sector of society as independent (cf. the theoretical framework of Karl Polanyi and the Substantivist school). I do not believe that the craftsmen during this period could act freely, travelling about and offering their services to a market. Instead they were tightly tied to the higher social strata (cf. Ramqvist 1990). Continental laws show that the smiths were not free, and the same thing is indicated by three Viking Age runestones, for example the one erected in Hørning, Denmark: "Toki, the Smith, erected this stone after Troels Gudmunds' son, who gave him freedom" (Fenger 1983:55, my transl., cf. Sawyer 1982:40). But the issue is hardly easy to solve. Runic inscriptions that name the person who made a certain object or carved a stone show at the same time that the smiths were very selfconfident.

There were specific rules that governed how to create a kenning, important rules that the skalds had to know. These rules, in turn, were grounded in myths. Thus, the poets also had to possess knowledge of the myths (Lie 1952; Lönnroth 1996, cf. the Prose Edda by Snorri). In that way the skalds came in possession of the myths, that is of a more or less secret knowledge. Thus, it is likely that the skalds were seen as powerful or perhaps even dangerous. Of course they were tied to those in power.

The knowledge of how to create images and objects was probably also restricted to certain persons. This may be the background to the peculiar position the smiths held in myths and in practice. The smiths had an ambiguous position in society, being in possession of crucial knowledge that made them respected yet at the same time necessary to control. The control directed at the smiths was therefore not only aimed at their products but, just as important, their knowledge.

Whether the art-forms and what they expressed were exclusive for an elite or were representative of the whole society, is perhaps not determinable from the pictures or skaldic verses themselves. I think, however, that we are dealing with a mentality rather than an exclusive ideology. That is, the conceptions that were expressed through the rhymes of poets and splendid objects of the craftsmen were more or less present throughout the whole society. However, the powerful families were successful in apprehending, making use of, and staging these myths and notions within the framework of the elite culture. Thus, the control over production was a facet 
of the firmly established power-ideology that maintained that those in power, above all others, could and should create wealth - $a r$ ok fridr.

\section{PLOTS, CRAFTS AND FECUNDITY}

In the beginning of the eighth century, at the north shore of the Ribe river, a thick layer of sand was spread at a distance of at least 200 meters. In this layer of sand parallel ditches were dug, 6-8 meters apart, which seem to have demarcated plots or building-sites. Some decades later the area was expanded and was now divided by a street, running parallel to the river. Symmetrically on both sides of the street there were plots (fig. 6). This place contained no permanent buildings and seems to have been used seasonally. A couple of hundred meters from this site, however, there were permanent buildings and graves, indicating another function and probably also other inhabitants than those who left traces at the plots along the river (Bencard \& Bender Jørgensen 1990; Jensen 1991).

Already from the start people had been conducting activities on the plots that left traces in the form of foreign objects and large amounts of waste from different crafts. The view that has received popular support is that the plots were let to merchants and craftsmen who regularly, every summer, travelled to this place under the protection of a king or magnate to buy, sell and produce different things. In illustrations often accompanying texts about Ribe (cf. the illustrations of Flemming Bau in Jensen 1991), this marketinterpretation is explicitly stated: products are put up to sale on tables and benches while the craftsmen sit in the background and work to produce new merchandise.

The parcelling out of plots is a new spatial structure, and it is usually seen as a clear indication that this place was planned by someone with authority and specific intentions. The spatial structure is also, analogous with conditions in High medieval towns and villages, thought of as resulting from the ambitions of an expanding royal power to extract taxes and duties from an existing trade-organization (Jensen 1991, cf. Hodges 1982; Ambrosiani \& Clarke 1991). At about the same time as the laying-out of Ribe, the village of Vorbasse, also in Jutland, was restructured. The new regular village plan, with equally long farm fences, seems to confirm the hypothesis that a system of taxation has been introduced (Egeberg Hansen et al. 1991). However, one may well doubt

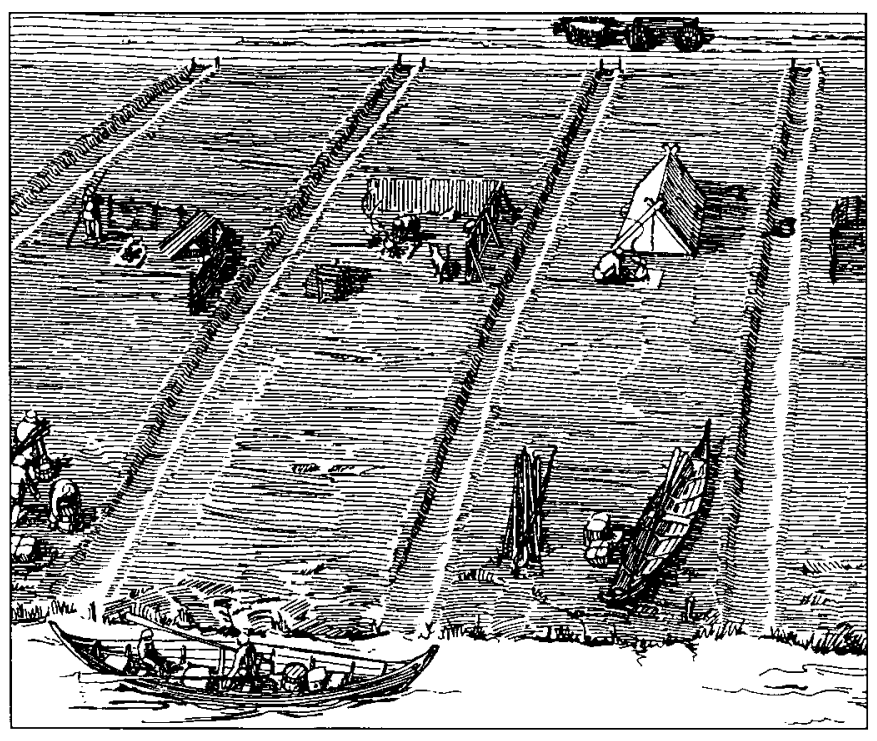

Fig. 6. "...the realm man has forced upon nature: the realm of the town" (Levi-Strauss 1968:50, my trans.). The picture shows the plot-structure in early Ribe (the market-place), as imagined when the first craftsmen moved in. (Frandsen \& Jensen 1986:29, drawing $F$. Bau). 
that regular taxes equivalent to the medieval taxation actually were present around the year 700 in Denmark. Of course, this does not imply that the extraction of agricultural surplus and control of land was not important (cf. Herschend 1997:71). The issue I am interested in, however, is how this was being done, that is, how this was understood and legitimized.

My suggestion is that there existed a metaphorical relationship between, on the one hand, the fertile field in the countryside and, on the other hand, the productive town-plot where smiths created valuable things.

In Ribe it seems as if the spatial lay-out (the parcelling out of plots) was a manipulation of the fertile grounds next to the permanent settlement. By this I mean that these grounds were not used for cultivation, as arable fields, but for other productive activities such as crafts. A similar pattern is found in Birka.

In the spatial organization of Birka it seems as if the so-called town-area, the Black Earth, was dominated by rather small buildings placed on plots belonging to, or used by, (among others) craftsmen. Houses belonging to aristocrats, however, were built outside and above the Black Earth, on terraces next to the town rampart (Holmquist Olausson 1993: ch. 7; Ambrosiani \& Eriksson 1997:41).

This spatial organization, can, I believe, on a structural level be seen as the house or hall-building lying next to, but separated from, the fenced and fertile arable fields.

The plots in Ribe and Birka remind more of the field than of the "mother of the field" (Sw. "tomt är tegs moder") as the medieval provincial law puts it, that is, the building plot (Sw. "tomt" or "toft"). This wording is usually seen from an economic and juridical perspective, that is, the formulation is said to denote that the building plot showed the individual farm's part of the regulated village and the taxes that accordingly should be paid. What the formulation do describe is that there existed a close connection between the building plot and the field, a connection that may well have been (also) of a cultural or ideological character.

The relationship between the arable field and the town-plot is expressed also in the fencing of the activities. The arable field was defined by fences or stone-enclosures that kept animals out of the field and protected the harvest. The building of fences was, in a quite pragmatic way, in itself an act that was "fertilizing". The fence could therefore in a figurative sense denote protection and fertility. The fenced plot created in that way associations to the earth, to the field, to those things that should grow and mature. In places like Ribe or Birka it is not the cultivating and harvesting of crops that shall be furthered, but the production of jewellery, beads, amulets, etc. And it is the lord of the place who (symbolically) accomplishes this by the founding of the site and the upholding of the boundary structure (fig. 7).

To further illuminate this connection, another material shall be put forth. The socalled gold-foil figures (Sw. guldgubbar) exist in several variants, and their dating ranges from the Migration period to the Viking Age. The most common gold-foil pictures show a man and a woman embracing each other (fig. 8). The picture has been interpreted as an illustration of the myth of how the god Freyr pursuades or forces the giantess Gerdr to celebrate a marriage with him. Gro Steinsland's interpretation is that the gold-foil figures were used in cult events that revolved around notions of the ruling family's divine origin (Steinsland 1990, cf. Fabech 1991; Lönnroth 1997). But other interpretations can of course be made.

These small golden couples have been found in the hall-building at Slöinge (House III, erected A.D. 710-720; Lundqvist 1997a). Gold-foil figures had been deposited, probably ritually (Ersgård 1996:104), in a post-hole next to the high settle. In the same post-hole was also found waste from different crafts, 
such as the manufacture of beads, metal objects, textiles, the working of garnets, etc.

The presence of such waste may seem puzzling, but can be related to the gold-foil figures through the Old Norse mythology. As mentioned previously, desirable objects (both material and immaterial, such as certain knowledge) and wealth could be brought forth when gods associated themselves with giantesses. The classical myth is, of course, the one about Freyr and Gerdr (Skirnismál). The name of the giantess, Gerdr, is related to the word gardr, meaning fence or enclosure (Sw. gärde, inhägnad). In 1909 Magnus Olsen claimed that Gerdr represented the fenced field, the field of barley. This interpretation may have been somewhat narrow, but according to Else Mundal it is still a plausible interpretation that Gerdr represents something that is enclosed, that has been claimed and is fertile or potentially fertile (Mundal 1990:13ff). My interpretation is that Gerdr is a personification of the territory or domain of the giants, that is "nature" (cf. above), which in this context should be seen as the yet unfinished, the potential, and should not be limited to denote the crops in the field. Thus, there existed a metaphorical connection between the furthering of crops and the furthering of valuable objects.

Perhaps the recently discovered finds in Husby, Glanshammar parish in Närke, Sweden may be put in the same context. Among other traces that indicate power and wealth, the site has building remains from almost the entire Late Iron Age, with a craftand workshop-area from the Merovingian period next to it. The crafts that are represented include bronze-smithery and bone- and antler-working. In the workshop-area the excavators also found gold-foil couples (Ekman 1998).

If the analogy with the arable field is accepted, there still remains to explain why places like Ribe and Birka were divided into many plots (why not just one big fenced
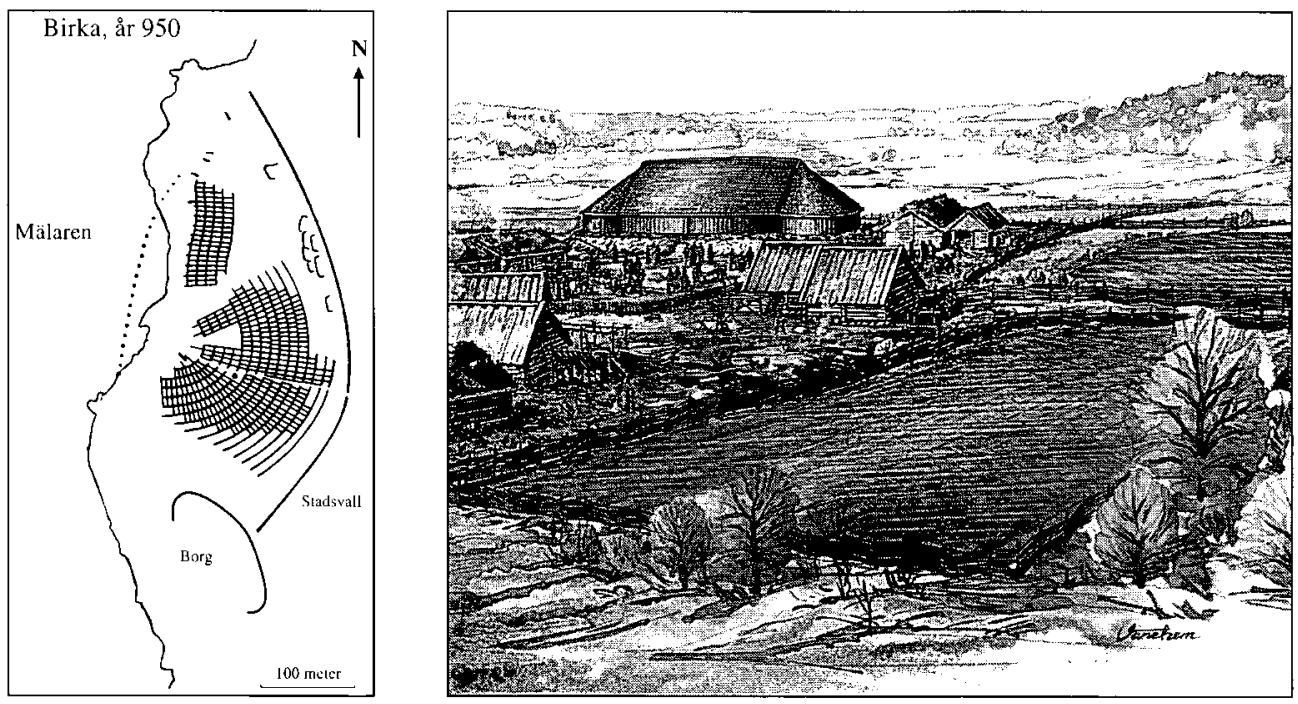

Fig. 7. The spatial organization of the Viking Age town of Birka can, on a structural level, be seen as a house or hall-building lying next to, but separated from, the fenced arable fields. The house terraces lying next to the town rampart are in close relation to the plots in the town area. (The reconstruction of Birka is from Ambrosiani \& Eriksson 1996:40. The reconstruction is not firmly established in all details.) The drawing of the farm is a reconstruction of the farm Sanda in Uppland. (From Aqvist 1998:228f, drawing $M$. Wänehem). 


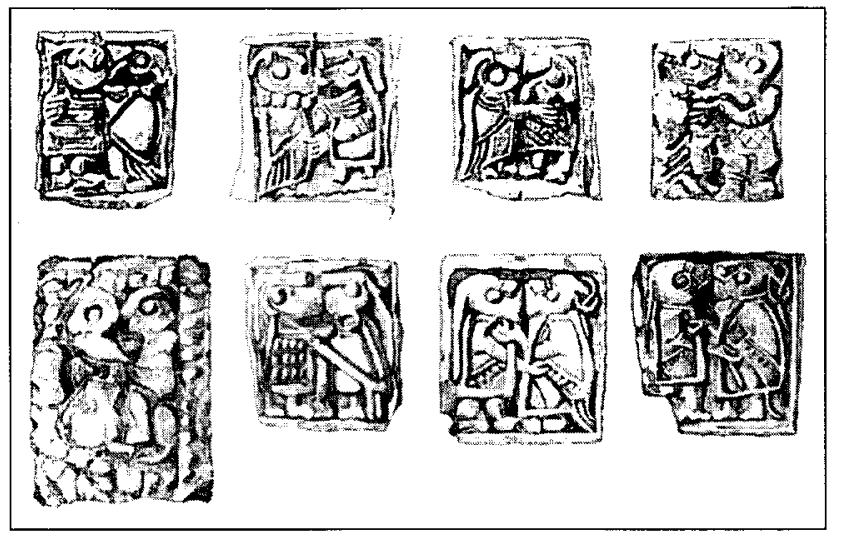

Fig. 8. These small golden couples have been found in the hallbuilding at Slöinge (erected A.D. 710-720; Lundqvist 1997a, fig. 5). The gold-foil figures had been deposited, probably ritually, in a post-hole next to the high settle. In the same post-hole was also found waste from different crafts. This act can, through Old Norse mythology, be related to beliefs concerning the conquest of the potentially fertile and the capturing of wealth.

area?). Who were intended to sit on these plots and manufacture beads and buckles, and why there? There is not enough room here to discuss these questions in any detail; they are far too complex. However, as stated above, I find it contextually not very reasonable to view the crafts carried out as a marketproduction. I do not believe that the craftsmen themselves owned their products and could convert them as they pleased. It also seems less likely that the smiths "belonged" to the king only, since the division into plots then seems rather meaningless. The remaining alternative, then, would be that the craftsmen were linked to other persons, possibly aristocrats or families belonging to the upper strata of society.

According to Per Ramqvist, the role of smiths and craftsmen changed during the Late Iron Age when a central power emerged and diminished the influence of the old aristocratic families. The smiths belonging to these families then became "redundant", and found themselves without any fixed social position. This in turn may have led to an altered "craftsmen-organization" (Ramqvist 1990:60f). I propose that we turn this reasoning upside-down and investigate whether a consciously changed "craftsmen-organization" in those areas where towns like Ribe and Birka emerged, may have led to a concentration of power. The plots where craftsmen and smiths worked can, just like the fields, have been involved in a metonymical relationship to the farms in the hinterland, and through them to the farm-owners or those in possession of the odal (cf. Gurevich 1985; Zachrisson 1994). To transfer the smiths to the towns denoted therefore, in a symbolic way, that the farm-owners were also moved into "the king's place". This must have been a strong manifestation of the concentration of power and its conditions. 


\section{REFERENCES}

Ambrosiani, B. 1985. Specialization and Urbanization in the Mälar Valley - a Question of Maturity. In: Society and Trade in the Baltic during the Viking Age. Acta Visbyensia VII. Visby,

Ambrosiani, B. \& Clarke, H. 1991. Towns in the Viking Age. Leicester University Press.

Ambrosiani, B. \& Ericsson, B. G. 1996. BIRKA Vikingastaden, del 5. Stockholm.

Andersson, K. 1995. Romartida guldsmide $i$ Norden III. Övriga smycken, teknisk analys och verkstadsgrupper. Aun 21. Uppsala.

Andrén, A. 1994. Signs of Communities. The Iconography of Early Towns in Denmark. Meddelanden från Lunds universitets historiska museum 1993-1994. New Series. Vol. 10. Pp. 9-20.

- 1998. Från antiken till antiken. Stadsvisioner i Skandinavien före 1700. In: Staden - himmel eller helvete. Tankar om människan i staden. Informationsförlaget, Stockholm.

Baetke, W. 1964. Yngvi und die Ynglinger. Eine quellenkritische Untersuchung über das nordische "Sakralkönigtum". Sitzungsberichte der sächsichen Akademie der Wissenschaften zu Leipzig. Philologisch-historische Klasse, Band 109, Heft 3. Berlin.

- 1973. Kleine Schriften. Geschichte, Recht und Religion in germanischen Schriftum. Herausgegeben von K. Rudolph \& E. Walter. Weimar.

Bauschatz, P. C. 1982. The Well and the Tree. World and time in Early Germanic Culture. The University of Massachusetts Press. Amherst.

Bencard, M. \& Bender Jørgensen, L. 1990. Excavation and Stratigraphy. In: Bencard, M., Bender Jørgensen, L. \& Brinch Madsen, H. (Eds). Ribe Excavations 1970-76. Text. Volume 4. Sydjysk Universitetsforlag. Esbjerg. Beowulf, see Collinder 1983; Klaeber 1950.

Bloch, M. 1992. Pray into Hunter. The politics of religious experience. Cambridge University Press. Cambridge.

Blæsild, B., Hardt, N., Michaelsen, K. K. \& Thomsen, P. O. 1993. Lundeborg-en handelsplads fra jernalderen. Skrifter fra Svendborg \& Omegns Museum. Bind 32. Ringe.

Bourdieu, P. 1977. The Berber House. In: Douglas, M. (Ed). Rules and Meanings. The Anthropology of Everyday Knowledge.
Hammondsworth.

- 1990. The Logic of Practice. Stanford, California.

Buchholz, 1971. Shamanism - the Testimony of Old Icelandic Literary Tradition. Mediaeval Scandinavia 4. Odense University Press. Pp. 7-20.

Burström, M. 1990. Järnframställning och gravritual. En strukturalistisk tolkning av järnslagg i vikingatida gravar i Gästrikland. Fornvännen. Stockholm. Pp. 261-271.

Bäck, M. 1997. No Island is a Society. Regional and Interregional Interaction in Central Sweden during the Viking Age. In: Andersson, H., Carelli, P. \& Ersgård, L. (Eds). Visions of the Past. Trends and Traditions in Swedish Medieval Archaeology. Lund Studies in Medieval Archaeology 19. Riksantikvarieämbetet, Arkeologiska undersökningar, Skrifter nr 24. Stockholm. Pp. 129-162.

Callmer, J. 1995. Hantverksproduktion, samhällsförändringar och bebyggelse. Iakttagelser från östra Sydskandinavien ca. 600-1 $100 \mathrm{e}$. Kr. In: Resi, H. G. (Ed). Produksjon og samfunn. Om erverv, spesialisering og bosetning $i$ Norden $i$ 1. artusen e.Kr. Beretning fra 2 . nordiske jernaldersymposium på Granavolden 1992. Varia 30. Universitetets Oldsaksamling. Oslo. Pp. 39-72.

Christiansen, I. 1982. Smed. Kulturhistoriskt Lexikon för Nordisk Medeltid, Band 16.

Christophersen, A. 1997. Byer? Hvilke byer? Tanker om byutviklingen i Norge i middelalderen. META nr 4. Lund.

Clunies Ross, M. 1994. Prolonged echoes. Old Norse myths in medieval Northern society. Vol. 1: The myths. Odense University Press. Odense.

Collett, D. P. 1993. Metaphors and representations associated with precolonial ironsmelting in eastern and southern Africa. In: Shaw, T., Sinclair, P., Andah, B. \& Okpoko, A. (Eds). The Archaeology of Africa. Food, metals and towns. One World Archaeology 20. London and New York. Pp. 499-511.

Collinder, B. 1983 (1954). B. Collinder (transl.), Beowulf. Natur och Kultur. Arlöv.

Drobin, U. 1991. Mjödet och offersymboliken i fornnordisk religion. In: Bäckman, L., Drobin, U. \& Berglie, P-A. (Eds). Studier-i religions- 
historia tillägnade Ake Hultkrantz professor emeritus den 1 juli 1986. Bokförlaget Plus Ultra. Pp. 97-141.

Duby, G. 1981. (1973). Krigare och bönder. Den europeiska ekonomins första uppsving 6001200. Stockholm.

Egeberg Hansen, T., Hvass, S. \& Mikkelsen, D. K. 1991. Landbebyggelserne i 7. århundrede. In: Mortensen, P. \& Rasmussen, B. M. (Eds). Fra Stamme til Stat i Danmark, 2. Hovdingesamfind og Kongemagt. Jysk Arkæologisk Selskabs skrifter XXII: 2, 1991. Aarhus. Pp. 17-28.

Ekman, T. 1998. Guld och gröna ängar - historien om Husby. Blick för Bergslagen. Arsbok för UV Bergslagen 1998. Stockholm. Pp. 7-16.

Eliade, M. 1978. The Forge and the Crucible. The University of Chicaco Press. Chicago and London.

Ersgård, L. 1996. Två stormansgårdar och deras landskap - en efterskrift. In: Lundqvist, L., Lindeblad, K., Nielsen, A.-L. \& Ersgård, L. Slöinge och Borg. Stormansgårdar i öst och $v a ̈ s t$. Riksantikvarieämbetet, Arkeologiska Undersökningar, Skrifter nr 18. Stockholm.

- 1997. Det starka landskapet. En arkeologisk studie av Leksandsbygden i Dalarna frän yngre järnålder till nyare tid. Riksantikvarieämbetet, Arkeologiska Undersökningar, Skrifter nr 21. Stockholm.

Fabech, C. 1991. Samfundsorganisation, religiøse ceremonier og regional variation. In: Fabech, C. \& Ringtved, J. (Eds). Samfundsorganisation og regional variation. Norden i romersk jernalder og folkevandringstid. Beretning fra 1. nordiske jernaldersymposium på Sandbjerg slot 11-15 april 1989. Jysk Arkæologisk Selskabs Skrifter XXVII. Århus.

Fenger, O. 1983. Gammeldansk ret. Dansk rets historie $i$ oldtid og middelalder. Århus.

Frandsen, L. B. \& Jensen, S. 1986. Hvor lå Ribe i vikingetiden? Et bidrag til Ribes topografi fra 8. til 11. århundrede. Kuml. Århus. Pp. 21 35.

Godelier, M. 1982. Economy and religion: an evolutionary optical illusion. In: Friedman, J. \& Rowlands, M. J. (Eds). The Evolution of Social Systems. Duckworth.

Gurevich, A, J. 1985. Categories of Medieval Culture. Routledge \& Kegan Paul. London.

Harrison, D. 1997. Centralorter i historisk forskning om tidig medeltid. In: Callmer, J. \&
Rosengren, E. (Eds). “...gick Grendel att söka det höga huset...". Arkeologiska källor till aristokratiska miljöer i Skandinavien under yngre järnålder. Hallands länsmuseers Skriftserie No 9/Gotarc C. Arkeologiska Skrifter No 17. Halmstad. Pp. 25-30

Haseloff, G. 1981. Die germanische Tierornamentik der Völkerwanderungszeit. Studien zu Salin's Stil I. Band I-III. Walter de Gruyter. Berlin, New York.

Hauck, K. 1985. Motivanalyse eines Dobbeltbrakteaten. Die Träger der goldenen Götterbilderamulette und die Traditionsinstanz der fünischen Brakteatenproduktion. Frühmittelalterliche Studien 19. Pp. 148-157.

Hedeager, L. 1997. Odins offer. Skygger af en shamanistisk tradition i nordisk folkevandringstid. Tor 29. Uppsala. Pp. 265-278.

Herschend, F. 1997. Historical or Textual Archaeology. An Archaeology of Critical Rereading. Current Swedish Archaeology, Vol. 5. Stockholm. Pp. 65-78.

Hodder, I. 1987. The contextual analysis of symbolic meanings. In: Hodder, I. (Ed). The archaeology of contextual meanings. Cambridge University Press. Cambridge. Pp. 1-10.

Hodges, R. 1982. Dark Age Economics. The Origins of Towns and Trade AD 600-1000. London.

Holmqvist Olausson, L. 1993. Aspects on Birka. Investigations and surveys 1976-1989. Thesis and Papers i Archaeology B:3. Stockholm.

Hultgård, A. 1993. Altskandinavische Opferrituale und das Problem der Quellen. In: Ahlbäck, T. (Ed). The problem of ritual. Scripta Instituti Donneriani Aboensis. Åbo. Pp. 221-259.

Hårdh, B. \& Larsson, L. 1998. Uppåkra - ett hövdinga- eller kungasäte. Fornvännen. Stockholm. Pp. 139-154.

Isendahl, C. 1997. Förhistorisk järnhantering i nordvästra Skåne. En studie med utgångspunkt från den vendeltida boplatsen i Haglekulla. In: Karsten, P. (Ed). Carpe Scaniam. Axplock ur Skånes förflutna. Riksantikvarieämbetet, Arkeologiska Undersökningar, Skrifter nr 22. Pp. 113-148.

Jensen, S. 1991. Ribes Vikinger. Den antikvariske Samling. Ribe.

Johansson, K. G. \& Malm, M. 1997. (transl. \& eds.). Snorres Edda. Stockholm.

Johansen, B. 1996. The Transformative Dragon. The Construction of Social Identity and the 
Use of Metaphors during the Nordic Iron Age. Current Swedish Archaeology, Vol. 4. Stockholm. Pp. 83-102.

- 1997. Ormalur. Aspekter av tillvaro och landskap. Stockholm Studies in Archaeology 14.

Klaeber, F. 1950. (Ed). Beowulf and the Fight at Finnsburg. Lexington.

Kristoffersen, S. 1995. Transformation in Migration Period Animal Art. Norwegian Archaeological Review, Vol. 28, No. 1. Pp. 1-17.

- 1997. Dyreornamentikkens sosiale tilhorighet og maktpolitiske samenheng. Nydamstil og Stil I i Sor- og Sorvestnorge. Bergen.

LeGoff, J. 1980. Time, Work, and Culture in the Middle Ages. The University of Chicago Press. Chicago and London.

Lévi-Strauss, C. 1963. Structural Anthropology. New York.

- 1968. Kulturspillror. (Tristes Tropiques, 1955). Stockholm.

Lie, H. 1952. Skaldestilstudier. Maal og Minne. Pp. 1-92.

Lindeblad, K. 1996. Borgs socken - förändringar $i$ tid och rum 200-1200 e Kr. In: Lundqvist, L., Lindeblad, K., Nielsen, A-L. \& Ersgård, L. Slöinge och Borg. Stormansgårdar i öst och väst. Riksantikvarieämbetet, Arkeologiska Undersökningar, Skrifter nr 18. Stockholm. Pp. 53-77.

Lindeblad, K. \& Nielsen, A.-L. 1997. Centralplatser i Norrköpingsbygden - förändringar i tid och rum 200-1200 e Kr. In: Callmer, J. \& Rosengren, E. (Eds). “... gick Grendel att söka det höga huset...". Arkeologiska källor till aristokratiska miljöer i Skandinavien under yngre järnålder. Hallands länsmuseers Skriftserie No 9/Gotarc C. Arkeologiska Skrifter No 17. Halmstad. Pp. 99-118.

Lindkvist, T. 1988. Plundring, skatter och den feodala statens framväxt. Organisatoriska tendenser i Sverige under övergången frän vikingatid till tidig medeltid. Opuscula historica Upsaliensia 1. Uppsala.

Lundqvist, L. 1996. Slöinge - en stormansgård från järnåldern. In: Lundqvist, L., Lindeblad, K., Nielsen, A-L. \& Ersgård, L. Slöinge och Borg. Stormansgårdar i öst och väst. Riksantikvarieämbetet, Arkeologiska Undersökningar, Skrifter nr 18. Stockholm. Pp. 9-52.

- 1997a. Slöinge: om ett pågående projekt. In: Callmer, J. \& Rosengren, E. (Eds). “...gick Grendel att söka det höga huset...". Arkeo- logiska källor till aristokratiska miljöer $i$ Skandinavien under yngre järnålder. Hallands länsmuseers Skriftserie No 9/Gotarc C. Arkeologiska Skrifter No 17. Halmstad. Pp. 89-98. - 1997b. Central Places and Central Areas in the Late Iron Age. Some Examples from Southwestern Sweden. In: Andersson, H., Carelli, P. \& Ersgård, L. (Eds). Visions of the Past. Trends and Traditions in Swedish Medieval Archaeology. Lund Studies in Medieval Archaeology 19. Riksantikvarieämbetet, Arkeologiska undersökningar, Skrifter nr 24. Stockholm. Pp. 179-198.

Lundqvist, L., Lindeblad, K., Nielsen, A-L. \& Ersgård, L. Slöinge och Borg. Stormansgårdar $i$ öst och väst. Riksantikvarieämbetet, Arkeologiska Undersökningar, Skrifter nr 18. Stockholm.

Lönnroth, L. 1996. Skaldemjödet i berget. Essaver om fornisländsk ordkonst och dess àteranvändning i nutiden. Atlantis, Stockholm.

- 1997. Hövdingahallen i fornnordisk myt och saga. Ett mentalitetshistoriskt bidrag till förståelsen av Slöingefyndet. In: Callmer, J. \& Rosengren, E. (Eds). “...gick Grendel att söka det höga huset...". Arkeologiska källor till aristokratiska miljöer $i$ Skandinavien under yngre järnålder. Hallands länsmuseers Skriftserie No 9/Gotarc C. Arkeologiska Skrifter No 17. Halmstad. Pp. 31-38.

Mauss, M. 1972 (1925). Gåvan. Argos Förlag, Uppsala.

Meulengracht Sørensen, P. 1991. Håkon den Gode og guderne. Nogle bemerkninger om religion og centralmakt $i$ det tiende århundrede - og om religion og kildekritikk. In: Mortensen, $\mathrm{P}$. \& Rasmussen, B. M. (Eds). Fra Stamme til Stat 2. Høvdingesamfund og Kongemakt. Jysk Arkæologisk Selskabs skrifter XXII:2. Aarhus. Pp. 235-244.

Mittner, L. 1955. Wurd. Das Sakrale in der Altgermanischen Epik. Bern.

Mundal, E. 1990. Forholdet mellom gudar og jotnar i norrøn mytologi i lys av det mytologiske namnematerialet. Studia Anthroponymica Scandinavica: Tidskrift for nordisk personnamnsforskning 8. Pp. 5-18.

Nielsen, A.-L. 1997. Pagan Cultic and Votive Acts at Borg. An Expression of the Central Significance of the Farmstead in the Late Iron Age. In: Andersson, H., Carelli, P. \& Ersgård, L. (Eds). Visions of the Past. Trends and Tradi- 
tions in Swedish Medieval Archaeology. Lund Studies in Medieval Archaeology 19. Riksantikvarieämbetet, Arkeologiska undersökningar, Skrifter nr 24. Stockholm. Pp. 373-392.

Odelman, E. 1986. (transl.) Rimbert: Ansgars liv. Boken om Ansgar. Stockholm. Pp. 13-77.

Olsen, M. 1909. Fra gammelnorsk myte og kultus. Maal og Minne.

Polanyi, K. 1957. The Economy as Instituted Process. In: Polanyi, K., Arensberg, C. \& Pearson, H. (Eds). Trade and Market in the Early Empires. Economics in History and Theory. Glencoe.

Ramqvist, P. G. 1990. Helgö - unikt handelscentrum eller vanlig bondgård? Fornvännen. Stockholm. Pp. 57-68.

Roth, H. 1986. Einführung in die Problematik, Rückblick und Ausblick. In: Roth, H. (Ed). Zum Problem der Deutung frühmittelalterlicher Bildinhalte. Jan Thorbecke Verlag, Sigmaringen. Pp. 9-24.

Rowlands, M. \& Warnier, J.-P. 1993. The magical production of iron in the Cameroon grassfields. In: Shaw, T., Sinclair, P., Andah, B. \& Okpoko, A. (Eds). The Archaeology of Africa. Food, metals and towns. One World Archaeology 20. London and New York. 512-550.

Sawyer, P.H. 1982. Kings and Vikings. Scandinavia and Europe AD 700-1100. Methuen. London and New York.

Schjødt, J. P. 1991. Relationen mellem aser og vaner og dens ideologiske implikationer. In: Steinsland, G. et al. (Eds). Nordisk Hedendom. Et Symposium. Odense.

- 1994. Heltedigtning og initiationsritualer. En religionsfænomenologisk analyse af den "unge" Sigurd Fafnersbanes historie. In: Schjødt, J. P. (Ed). Myte og Ritual $i$ det forkristne Norden. Et symposium. Odense Universitetsforlag. Odense. Pp. 113-128.
Skre, D. 1998. Herredommet. Bosetning og besittelse på Romerike 200-1350 e. Kr. Universitetsforlaget, Oslo.

Steinsland, G. 1990. De nordiske gullblekk med parmotiv og norron fyrsteideologi. Et tolkningsforslag. Collegium Medievale 1990/1, Vol. 3. Pp. 73-94.

- 1991. Det hellige bryllup og norron kongeideologi. En analyse av hierogami-myten $i$ Skirnismál, Ynglingatal, Háleygjatal og Hyndlyljód. Oslo.

Stolpe, H. \& Arne, T. J. 1912. Graffältet vid Vendel. KVHAA. Monografier. 3. Stockholm.

Ström, F. 1985/1961/. Nordisk hedendom. Tro och sed i förkristen tid. Arlöv.

Sturluson, Snorri. See Johansson, K. G. \& Malm, $\mathrm{M}$.

Terry, P. 1969. Poems of the Vikings: The Elder Edda. Indianapolis and New York.

Vierck, H. 1967. Ein Relieffibelpaar aus Nordendorf in Bayerisch Schwaben. Zur Ikonographie des germanischen Tierstils I. Bayerische Vorgeschichtsblätter. Jahrgang 32. Pp. 105143.

Vita Anskarii, see Odelman 1986.

Zachrisson, T. 1994. The Odal and Its Manifestation in the Landscape. Current Swedish Archaeology, Vol. 2. Pp. 219-238.

Åberg, N. 1925. Förhistorisk nordisk ornamentik. Uppsala.

Åqvist, C. 1992. Pollista and Sanda - two Thousand-year-old Settlements in the Mälaren region. In: Ersgård, L., Holmström, M. \& Lamm, K. (Eds). Rescue and Research. Reflections of Society in Sweden 700-1700 A.D. Riksantikvarieämbetet. Arkeologiska undersökningar. Skrifter No 2. Stockholm.

- 1998. Gărden på landet - en spegling av staden. In: Bratt, P. (Ed). Forntid i ny dager. Arkeologi $i$ Stockholmstrakten. Stockholms läns museum. Stockholm. Pp. 222-230. 
